\title{
IDENTIFICATION OF STEROIDS OF HIGH ACTIVITY FOR CONTROL OF THE OESTROUS CYCLE IN THE DAIRY HEIFER
}

\author{
D. F. WISHART \\ Searle Research Laboratories, G. D. Searle $\mathcal{E}^{\circ}$ Co. Ltd, \\ High Wycombe, Bucks.
}

(Received 29th February 1972, accepted 20th March 1972)

Recently, a small series of screening experiments have been conducted with a view to identifying synthetic steroids of high activity for control of the oestrous cycle in mature Friesian heifers. Five synthetic steroids and progesterone were tested in cyclical animals. The activity of the steroids was assessed by their ability to suppress both oestrus and ovulation following a series of daily injections. The steroids were all chosen on the basis of their biological activity profiles in conventional laboratory animal bioassays.

The synthetic steroids were:

1. SC5914 17 $\alpha$-ethyl-19-nor-testosterone

2. SC9880 $17 \alpha$-acetoxy- $9 \alpha$-fluoro-11 $\beta$-hydroxy-4-pregnene-3,20 dione

3. SC18310 $11 \beta$-methyl-17 $\alpha$ ethyl-19-nor-testosterone

4. SC19773 3-(3-oxo-11 $\beta$-methyl-17 $\beta$-hydroxyester-5(10)-en-17 $\alpha$-yl) propionic acid Y-lactone

5. SC21009 $17 \alpha$-acetoxy-11 $\beta$-methyl-19-nor-preg-4-ene-20,dione.

All were dissolved in sesame oil to which $10 \%$ benzyl alcohol was added as a bacteriostatic agent. The test substances were each tested at five dose levels and at each dose level two cyclical heifers received fourteen daily intramuscular injections from the 14th day of the oestrous cycle onwards. Two animals were retained for control purposes. These received injections of solvent only. The doses and concentrations employed are shown in Table 1. For 21 days from the date of the first injection, observations were made twice daily for the onset of oestrus using either a vasectomized bull or heifer-to-heifer behaviour. Every 3rd day, a rectal examination was made to determine whether ovulation had occurred during the treatment period. Results are shown in Table 2. The lowest daily doses at which oestrus and ovulation suppression were obtained in both heifers were $45.0 \mathrm{mg}$ progesterone; 5.4 mg SC5914; $2.4 \mathrm{mg} \mathrm{SC9880;0.45} \mathrm{mg}$ SC19773 and 0.14 mg SC21009. Control animals exhibited oestrus, and ovulated between the 7th and 8th day of injection. All heifers receiving steroids came into oestrus within 7 days of the last injection.

It remains to be seen whether any of the steroids completely duplicate the action of progesterone. The interaction between oestrogen and progesterone in the sexual behaviour of the bovine has not been clearly defined. It is not yet possible to devise a bioassay system for the heifer similar to that which has been 
developed in the ewe (Shelton, 1965). In such a system, the test substance is substituted for progesterone in a priming series of injections in the ovariectomized animal before injecting physiological quantities of oestrogen. Carrick \& Shelton (1969) have shown that the oestrogen-progesterone relationship in the ovariectomized heifer is different from that in the ewe. The interaction seems to be more complex although sensitivity on a weight basis appears to be

\section{TABLE 1}

TEST STEROID CONCENTRATIONS AND DOSAGES AT FIVE
DIFFERENT DOSE LEVELS

\begin{tabular}{|c|c|c|c|c|c|c|}
\hline & \multirow{2}{*}{$\begin{array}{c}\text { Concentration } \\
(\mathrm{mg} / \mathrm{ml})\end{array}$} & \multicolumn{5}{|c|}{ Dose level } \\
\hline & & 1 & 2 & 3 & 4 & 5 \\
\hline \multirow{3}{*}{$\left.\begin{array}{l}\text { Progesterone } \\
\text { SC5914 } \\
\text { SC9880 } \\
\text { SC18310 } \\
\text { SC19773 } \\
\text { SC21009 } \\
\text { Control }\end{array}\right\}$} & $\begin{array}{r}20.0 \\
2.4 \\
0.4 \\
1.0\end{array}$ & $\begin{array}{c}10.0 \\
1.0 \\
0.66 \\
0.44\end{array}$ & $\begin{array}{c}14.0 \\
1.6 \\
1.0 \\
0.66\end{array}$ & $\begin{array}{r}20.0 \\
2.4 \\
1.6 \\
1.0\end{array}$ & $\begin{array}{r}30.0 \\
3.6 \\
2.4 \\
1.6\end{array}$ & $\begin{array}{r}45 \cdot 0 \\
5 \cdot 4 \\
3 \cdot 6 \\
2 \cdot 4\end{array}$ \\
\hline & $0 \cdot 1$ & 0.01 & 0.14 & 0.2 & $0 \cdot 3$ & 0.45 \\
\hline & & \multicolumn{5}{|c|}{$2.5 \mathrm{ml}$ Sesame oil } \\
\hline
\end{tabular}

The dosage of each steroid at the five different dose levels is expressed in $\mathrm{mg} / \mathrm{day}$.

TABLE 2

EFFEGT OF STEROIDS AT FIVE DIFFERENT DOSE LEVELS ON OESTRUS AND OVULATION IN HEIFERS

\begin{tabular}{l|ccccc}
\hline & \multicolumn{5}{|c}{ Dose level } \\
\cline { 2 - 6 } & 1 & 2 & 3 & 4 & 5 \\
\hline Progesterone & -+ & -- & -+ & -+ & ++ \\
SC5914 & -- & -- & $* *$ & $*+$ & ++ \\
SC9880 & -- & -+ & -+ & ++ & ++ \\
SC18310 & -- & -- & $-\frac{1}{+}$ & -+ & ++ \\
SC19773 & -- & -- & $*+$ & -+ & ++ \\
SC21009 & -+ & ++ & ++ & ++ & ++ \\
Control & -- & -- & -- & -- & -- \\
\hline
\end{tabular}

$t=$ oestrus and ovulation suppressed in one heifer; * = ovulation occurred with oestrus in one heifer; $-=$ neither oestrus nor ovulation suppressed.

comparable. Physiological doses of oestrogen induce oestrus in the heifer but do not cause a refractory state. When much larger doses of oestrogen are employed, a refractory state is produced and alternating progesterone influence is then necessary if oestrus is to be induced by administration of physiological quantities of oestrogen. Thus, the heifer once treated with larger quantities of oestrogen behaves in the same way as the ewe, and it may eventually, therefore, be possible to develop a bioassay system in the heifer similar to that for the ewe.

\section{REFERENCES}

Garrick, M. J. \& Shelton, J. N. (1969) Oestrogen-progesterone relationships in the induction of oestrus in the spayed heifer. 7. Endocr. 45, 99.

SHEzton, J. (1965) Identification of progestogens of high activity for the control of the oestrous cycle in the sheep. Nature, Lond. 206, 156. 